\title{
Identification of seed-borne fungi of farmer-saved seeds of pepper and their control with some selected botanicals
}

\author{
E. GYASI*, C. KWOSEH \& E. MOSES \\ (E.G.: Plant Pathology Section, CSIR-Plant Genetic Resources Research Institute, Bunso, \\ Ghana; C.K.: Department of Crop and Soil Sciences, Kwame Nkrumah University of \\ Science and Technology (KNUST), Kumasi, Ghana \& E.M.: Plant Pathology Division, \\ CSIR-Crops Research Institute, Fumesua, Kumasi, Ghana) \\ *Corresponding author's email: ericgyasi2010@yahoo.com
}

\begin{abstract}
A survey was conducted on the source of planting materials and pre-planting seed treatment practice by pepper farmers in Obenemasi and Ofoase-Kokoben communities in the Ashanti Region of Ghana using a well-structured questionnaire in June, 2011. Seed health test was conducted on 40 farmer-saved pepper seed samples collected from the farmers interviewed using the blotter method in the laboratory. Efficacy of garlic, ginger and neem botanical extracts in managing the seed-borne fungi of pepper seeds was also investigated in this study in-vitro. Results of the questionnaire-based survey indicated that, majority of respondent farmers, about $75 \%$ recycled seeds from previous harvest, $20 \%$ of respondents also used seeds obtained from friends and 5\% obtained their pepper seeds from local markets. Nine genera of fungi including 12 species were identified from the pepper seed samples collected. The three botanical extracts proved effective as Mancozeb in controlling one or more of the test seed-borne fungi. Garlic aqueous extract $(60 \%(\mathrm{w} / \mathrm{v}))$ was effective as Mancozeb in controlling Colletotrichum capsici and Colletotrichum gloesporioides. Ginger aqueous extract $(60 \%(\mathrm{w} / \mathrm{v}))$ was also effective against seed-borne Fusarium and Aspergillus spp. whereas aqueous neem extract $(60 \%(\mathrm{w} / \mathrm{v}))$ was effective in controlling Aspergillus flavus and Aspergillus niger.
\end{abstract}

Keywords: Botanical extracts; Mancozeb; Seed-borne fungi; Seed samples; Survey Original scientific paper. Received 30 Sep 2019; revised 04 Feb 2020

\section{Introduction}

Chili pepper (Capsicum annuum L.) is a herbaceous perennial dicotyledonous plant of the family Solanaceae. It is also called cayenne, chili, bird's eye or red pepper (Tindall, 1983). Chili has many culinary advantages and contains chemicals such as steam-volatile oils, fatty oils, capsaicinoids, carotenoids, vitamins, protein, fibre and mineral elements (Bosland \& Votava, 2003). Many chili constituents are important for nutritional value, flavour, aroma, texture and colour. Chilies are low in sodium and cholesterol free, rich in vitamins A and $\mathrm{C}$, and are a good source of potassium, folic acid and vitamin E (Bosland \& Votava, 2003). Fresh green chili peppers contain more vitamin $\mathrm{C}$ than citrus fruits and fresh red chili has more vitamin A than carrots (Marin et al., 2004; Osuna-García et al., 1998). Capsaicinoids are alkaloids that make hot chili pungent.

In Ghana, pepper is the second most popular vegetable after tomato (Schippers, 2000).

Ghana Jnl Agric. Sci. 55 (1), 43 - 53

GJAS is an Open Access Journal and distributed under the terms of the Creative Commons (CC) License [CC BY 4.0] 
Pepper cultivation is a major source of livelihood for many farmers in Ghana. Although most of the income generated is for local consumption, proceeds from export to a burgeoning European market are also a vital source of income for the country and farmers.

Several research works have reported on seedborne fungi of several solanaceous and other crops in different countries (Chauhan \& Patel, 2018; Dinker \& Gunay, 2018; Al-Askar et al., 2013; Chigoziri \& Ekefan, 2013; Debnath et al., 2012; Makelo, 2010; Balogun et al., 2005) but little information is available on seedborne fungi of pepper seeds in different pepper growing communities in Ghana. Seed-borne fungi are either pathogenic or saprophytic. Pathogenic seed-borne fungi infect seeds in the field and reduce seed vigour, weaken the plant at its initial growth and cause disease epidemic in the field (Debnath et al., 2012; Mathur \& Kongsdal, 2003; Maude, 1996). Saprophytic seed-borne fungi affect seeds during storage and cause seed discoloration, reduce seed weight and reduce seed germination (Al-Askar et al., 2013). According to Isaac (1992), over 70\% of farmers in developing countries use their own saved seeds continuously for planting. Continuous use of farmer-saved seeds in the absence of seed treatment could contribute to high incidence of seed-borne diseases. Seed treatment with synthetic chemicals has been used globally and in Ghana especially, farmers' heavy reliance on chemical fungicides with its attendant consequences is a matter of great national concern. There are reports of negative effects of using chemicals on farmers' income and health, and toxic contamination to the environment, particularly in developing countries (Okigbo, 2004; Voorrips et al., 2004). Plant extracts, essential oils, gums, resins etc have been shown to exert biological activity against plant fungal pathogens in-vitro and invivo and can be used as bio-fungicidal products (Jalili et al., 2010; Fawzi et al., 2009). Natural plant extracts show limited field persistence and have a shorter shelf life and no residual threats, generally safe to humans and environment in comparison to conventional synthetic chemical pesticides (Nuzhat \& Vidyasagar, 2013). Garlic, ginger and neem botanical extracts have been proven to be effective in controlling seed-borne fungi (Syed, 2012; Fawzi et al., 2009; Ines et al., 2008; Foster \& Yue, 1992). Controlling seed-borne pathogens through the development and application of appropriate seed treatment brings about reduction in crop yield losses (Korpraditskul et al., 1999; Jeyalakshmi \& Seetharaman, 1998). The aims of this study were to identify the sources of planting materials and pre-planting seed treatment practice by the pepper farmers, document seed-borne fungi associated with farmer saved-seeds of pepper from Obenemasi and Ofoase-Kokoben in the Ashanti Region of Ghana and to explore the possibility of managing the seed-borne fungi with garlic, ginger and neem botanical extracts.

\section{Materials and Methods}

Survey: Sources of planting materials and preplanting seed treatment practice

Questionnaire-based survey was undertaken in two major pepper growing communities in the Ashanti Region of Ghana on sources of planting materials and pre-planting seed treatment practice in June, 2011. The two communities were Obenemasi in the Asante Akim Central Municipality and OfoaseKokoben in the Bekwai Municipality (Fig.1). 20 farmers in each community were randomly selected and individually interviewed using a structured-questionnaire. 


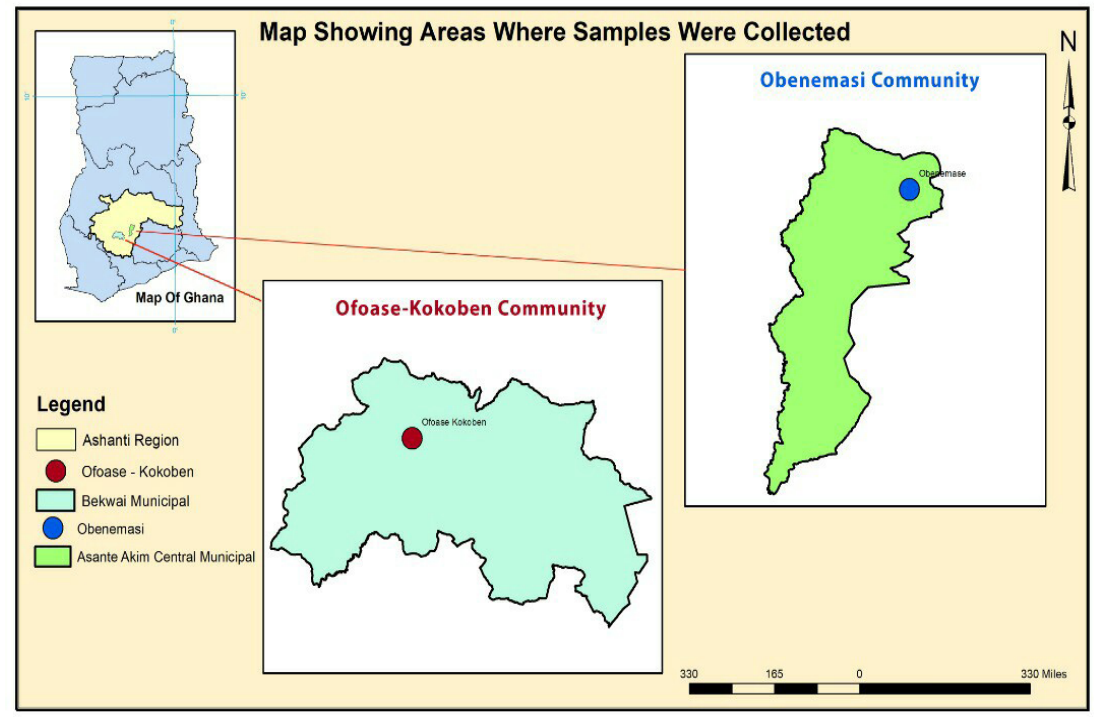

Fig. 1: Map showing communities where the samples were collected

\section{Collection of farmer-saved pepper seed} samples for seed health test

Samples of the pepper seeds were collected from each of the farmers interviewed in each of the two communities (Ofoase-Kokoben and Obenemasi). A total of 40 pepper seed samples were collected from the farmers interviewed. Most of the farmers in the two communities cultivate the "Meko hwam" pepper variety. All the seed samples collected were therefore of the "Meko hwam" variety. The seed samples collected were saved in brown paper envelopes and stored in a refrigerator at a temperature of $5^{\circ} \mathrm{C}$ at the Plant Pathology Laboratory of the CSIR-Crops Research Institute, Fumesua until needed.

Isolation and identification of fungi species from farmer-saved pepper seeds

Samples of the farmer-saved seeds obtained from interviewed farmers were examined for the presence of fungi using the moist blotter method (ISTA, 2005). 200 seeds of each sample were used in the study. 25 seeds were counted from each sub-sample and placed on three layers of moistened blotters in sterile plastic Petri dishes. Each sample was replicated four times. The plated seeds were then incubated at $24 \pm 1^{\circ} \mathrm{C}$ under alternating cycles of $12 / 12$ hours of near ultra-violet light and darkness for seven days. On the eighth day of incubation, the seeds were examined for the presence of fungal growth with the aid of a stereo microscope (Leica, CLS 100, Germany). The seed-borne fungi were identified based on the colony morphology, colour of mycelium and the shape and other characteristics of conidia produced with the aid of laboratory manuals developed by Mathur and Kongsdal (2003) and Barnett and Hunter (1998). The examination of the seeds for the seed-borne fungi was done at CSIR- Crops Research Institute, Fumesua. The 
frequency of occurrence of each type of fungus identified was calculated using the formula;

Number of infected samples $\times 100 \%$

Total number of samples tested

Efficacy of botanical extracts in controlling the seed-borne fungi of pepper Ginger (Zingiber officinale Rosc.), garlic (Allium sativum L.) and neem (Azadirachta indica A. Juss) were the botanical extracts used in the study of the efficacy of botanical extracts in controlling seed-borne fungi of pepper. Mancozeb which is a synthetic fungicide was used as a check. Preparation of the aqueous botanical extracts and treatment of seeds with the extracts and the suspension of the chemical fungicide were done at the Plant Pathology Laboratory of the CSIR- Crops Research Institute, Fumesua.

\section{Preparation of aqueous ginger rhizome extract}

Rhizomes of ginger bought from the commercial area of the Kwame Nkrumah University of Science and Technology, Kumasi were peeled and washed thoroughly with water. The rhizomes were blended into a fine paste with an electric blender (Binatone, BLG401, Hong Kong) at $4000 \mathrm{rpm}$ for $10 \mathrm{~min} .60$ grams of the ginger paste was put into a beaker and $100 \mathrm{ml}$ of sterile distilled water added and stirred thoroughly with a glass rod to obtain an aqueous extract with a concentration of $60 \%$ (w/v) (Fig.2).

\section{Preparation of aqueous garlic extract} Bulbs of garlic also bought from the commercial area, Kwame Nkrumah University of Science and Technology, were peeled and washed thoroughly with tap water. They were blended into a fine paste with an electric blender (Binatone, BLG-401, Hong Kong) as described above. 60 grams of the garlic paste was put into a beaker and $100 \mathrm{ml}$ of sterile distilled water added and stirred thoroughly with a glass rod to obtain an aqueous extract with a concentration of $60 \%(\mathrm{w} / \mathrm{v})$ (Fig. 3).

Preparation of aqueous neem leaf extract

Fresh leaves of neem obtained from Ayeduase behind the Shalom Hostel, near Kwame Nkrumah University of Science and Technology, were washed thoroughly with tap water. The fresh leaves were blended into a fine paste with an electric blender (Binatone, BLG401, Hong Kong) at $4000 \mathrm{rpm}$ for 10 minutes. 60 grams of the neem paste was put into a beaker and $100 \mathrm{ml}$ of sterile distilled water was added and stirred thoroughly with a glass rod to obtain an extract with a concentration of $60 \%$ (w/v) (Fig. 4).

\section{Preparation of Mancozeb solution}

Mancozeb was obtained from an agrochemical shop in Kejetia, Kumasi. Mancozeb solution was prepared by following the manufacturer's recommendation. About $7.5 \mathrm{~g}$ of the Mancozeb fungicide powder was taken and dissolved in 1 $\mathrm{L}$ distilled water (Fig. 5). After that an aliquot of $40 \mathrm{ml}$ was taken for use as a check in the experiment. 


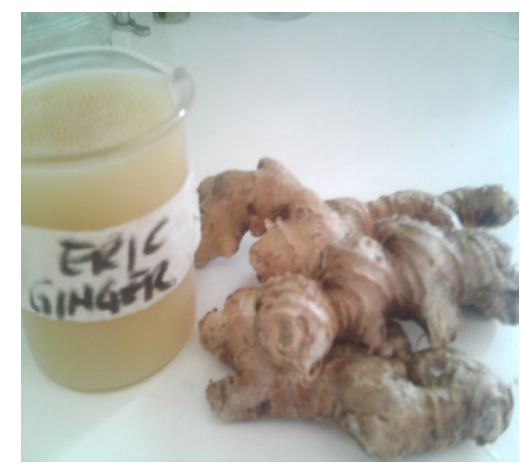

Fig. 2: Ginger and its aqueous extract

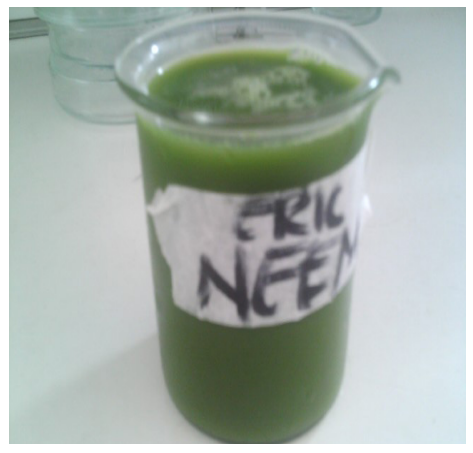

Fig. 4: Neem aqueous extract

Treatment of the pepper seeds with the prepared aqueous botanical extracts and mancozeb Seed sample of Capsicum annuum var. 'Meko hwam" collected from the farmers with the highest frequency of occurrence of seedborne fungi was used in the study. 250 seeds were soaked in each of the prepared aqueous extracts, sterilized distilled water (control) and the mancozeb suspension separately for 24 hours. The mancozeb suspension served as a standard check. The soaked seeds were then air dried in a Laminar Flow Hood for 20 minutes and then platted on blotters following the ISTA (2005) procedure. The plated seeds were

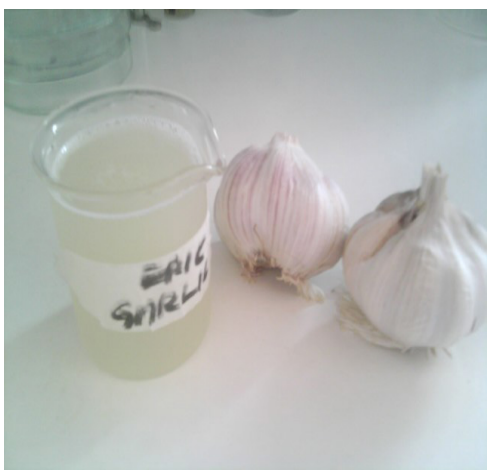

Fig. 3: Garlic and its aqueous extract

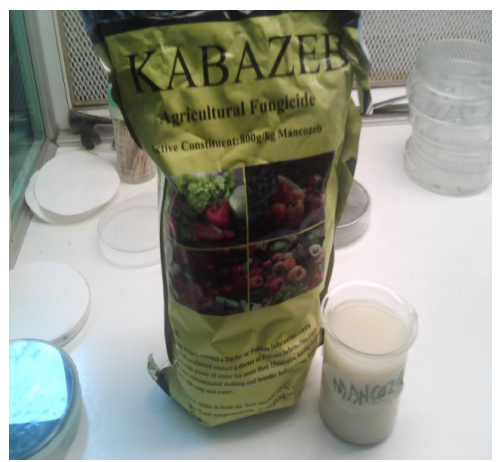

Fig. 5: Mancozeb and its suspension

then incubated at $24 \pm 1{ }^{\circ} \mathrm{C}$ under alternating cycles of 12/12 hours of near ultra-violet light and darkness for seven days. On the eighth day of incubation, the seeds were examined for the presence of fungal growth with the aid of a stereo microscope (Leica, CLS 100, Germany) at the Plant Pathology Laboratory of CSIR-CRI. The seed-borne fungi were identified based on the colony morphology, colour of mycelium and the shape and other characteristics of conidia produced with the aid of laboratory manuals developed by Mathur and Kongsdal (2003) and Barnett and Hunter (1998). The experimental design used was 
factorial arranged in completely randomized design (CRD) with three replications. Data were collected on the frequencies of occurrence of fungi identified on the pepper seeds soaked in sterile distilled water, the botanical extracts and mancozeb suspension and was expressed as percentage of control of the fungi by the aqueous botanical extracts and mancozeb using the formula;

\section{$\frac{\text { f.c }- \text { f.t }}{\text { f.c }} \times 100 \%$}

Where f.c is the occurrence of the fungus after treatment with the control (water) and f.t is the occurrence of fungus after treatment with the botanical extract and mancozeb.

\section{Data analysis}

Statistix 9.1 was used to analyze the data. Differences in treatment means were compared for significance using Least Significance Difference at Probability less or equal to 0.05 $(\mathrm{p} \leq 0.05)$.

\section{Results}

About $75 \%$ of the pepper farmers recycled were extracted from rotten pepper fruits from previous harvest as planting material. $20 \%$ of the farmers obtained their seeds from friends who saved some of the pepper seeds from previous harvest and $5 \%$ of the farmers also purchase seeds from local markets (Table 1). None of the farmers interviewed provided a seed treatment before sowing pepper seeds (Table 2).

TABLE 1

Sources of planting materials of pepper farmers in Ofoase-Kokoben and Obenemasi

\begin{tabular}{lc}
$\begin{array}{l}\text { Source of seeds for } \\
\text { planting by farmers }\end{array}$ & $\begin{array}{c}\text { \% acquisition by } \\
\text { farmers }\end{array}$ \\
\hline Farmers' own seeds & 75 \\
From friends & 20 \\
Local markets & 5 \\
\hline
\end{tabular}

TABLE 2

Pre-planting seed treatment practice by the pepper farmers in Ofoase-Kokoben and Obenemasi

\begin{tabular}{llll}
\hline Community & $\begin{array}{l}\text { No. of } \\
\text { respondent } \\
\text { farmers }\end{array}$ & $\begin{array}{l}\text { No. of } \\
\text { farmers } \\
\text { who treat } \\
\text { their pepper } \\
\text { seeds before } \\
\text { sowing }\end{array}$ & $\begin{array}{l}\text { Percentage } \\
\text { farmers who } \\
\text { treat their } \\
\text { seeds before } \\
\text { sowing (\%) }\end{array}$ \\
\hline $\begin{array}{l}\text { Ofoase-Koko- } \\
\text { ben }\end{array}$ & 20 & 0 & 0 \\
Obenemasi & 20 & 0 & 0 \\
\hline
\end{tabular}

Identified seed-borne pathogens of pepper seeds in the two communities studied

Colletotrichum capsici was the most frequent fungus identified on the seed samples collected from Ofoase-Kokoben (Table 3). Fusarium solani and Fusarium verticillioides were identified on 35.0 and $30.0 \%$, respectively, from seed samples from the Ofoase-Kokoben community. Aspergillus flavus was identified on $25.0 \%$ of seed samples collected from the Ofoase-Kokoben community (Table 3). Only one sample out of the 20 samples tested was infected by $\mathrm{Col}$ letotrichum gloesporioides, Curvularia pallescens, Myrothecium species, Macrophomina phaseolina, Cladosporium sphaerospermum and Penicillium species and recorded a fungal incidence of $5.0 \%$ each (Table 3 ).

Colletotrichum capsici was the most frequent fungus identified on seed samples from Obenemasi (Table 4). Fusarium solani and Fusarium verticillioides were identified on 30.0 and $25.0 \%$, respectively from seed samples from the Obenemasi community (Table 4). 
TABLE 3

Incidence of infection of pepper seeds by fungal species from samples from Ofoase-Kokoben

\begin{tabular}{lccc}
\hline Fungal species & $\begin{array}{c}\text { Total No. } \\
\text { of samples } \\
\text { tested }\end{array}$ & $\begin{array}{c}\text { No. of } \\
\text { infected } \\
\text { samples }\end{array}$ & $\begin{array}{c}\text { Incidence } \\
\text { of fungi } \\
\text { (\%) }\end{array}$ \\
\hline $\begin{array}{l}\text { Fusarium } \\
\text { verticillioides }\end{array}$ & 20.0 & 6.0 & 30.0 \\
Fusarium solani & 20.0 & 7.0 & 35.0 \\
Colletotrichum capsici & 20.0 & 8.0 & 40.0 \\
$\begin{array}{l}\text { Colletotrichum } \\
\text { gloesporioides }\end{array}$ & 20.0 & 2.0 & 10.0 \\
$\begin{array}{l}\text { Curvularia pallescens } \\
\text { Myrothecium species }\end{array}$ & 20.0 & 1.0 & \\
Macrophomina & 20.0 & 1.0 & 5.0 \\
phaseolina & 20.0 & 1.0 & 5.0 \\
Rhizopus species & 20.0 & 2.0 & 5.0 \\
Aspergillus niger & 20.0 & 3.0 & 10.0 \\
Aspergillus flavis & 20.0 & 5.0 & 15.0 \\
$\begin{array}{l}\text { Cladosporium sphaero- } \\
\text { spermum }\end{array}$ & 20.0 & 1.0 & 25.0 \\
Penicillium species & 20.0 & 1.0 & 5.0 \\
\hline
\end{tabular}

Aspergillus flavus were identified on $15.0 \%$ of seed samples collected from the Obenemasi community (Table 4). Only one sample out of the 20 samples from Obenemasi tested was infected by Curvularia pallescens, Myrothecium species, Macrophomina phaseolina, Aspergillus niger and Penicillium species and recorded a fungal incidence of $5.0 \%$ each.

TABLE 4

Incidence of infection of pepper seeds by fungal species from samples from Obenemasi

\begin{tabular}{lccc}
\hline $\begin{array}{l}\text { Fungal } \\
\text { species }\end{array}$ & $\begin{array}{c}\text { Total No. } \\
\text { of samples } \\
\text { tested }\end{array}$ & $\begin{array}{c}\text { No. of } \\
\text { infected } \\
\text { samples }\end{array}$ & $\begin{array}{c}\text { Incidence of } \\
\text { fungi } \\
\text { (\%) }\end{array}$ \\
\hline $\begin{array}{l}\text { Fusarium } \\
\text { verticillioides }\end{array}$ & 20.0 & 5.0 & 25.0 \\
$\begin{array}{l}\text { Fusarium } \\
\text { solani }\end{array}$ & 20.0 & 6.0 & \\
$\begin{array}{l}\text { Colletotrichum } \\
\text { capsici }\end{array}$ & 20.0 & & 30.0 \\
$\begin{array}{l}\text { Colletotrichum } \\
\text { gloesporioides }\end{array}$ & 20.0 & 7.0 & 35.0 \\
$\begin{array}{l}\text { Curvularia } \\
\text { pallescens }\end{array}$ & 20.0 & 3.0 & \\
& & & \\
\end{tabular}

\begin{tabular}{lccc}
$\begin{array}{l}\text { Myrothecium } \\
\text { species }\end{array}$ & 20.0 & 1.0 & 5.0 \\
$\begin{array}{l}\text { Macrophomina } \\
\text { phaseolina }\end{array}$ & 20.0 & 1.0 & 5.0 \\
$\begin{array}{l}\text { Rhizopus } \\
\text { species }\end{array}$ & 20.0 & 2.0 & 10.0 \\
$\begin{array}{l}\text { Aspergillus } \\
\text { niger }\end{array}$ & 20.0 & 1.0 & 5.0 \\
$\begin{array}{l}\text { Aspergillus } \\
\text { favus }\end{array}$ & 20.0 & 3.0 & 15.0 \\
$\begin{array}{l}\text { Penicillium } \\
\text { species }\end{array}$ & 20.0 & 1.0 & \\
& & & 5.0 \\
\hline
\end{tabular}

Control of seed-borne pathogens of pepper with botanical extracts

Garlic aqueous extract and mancozeb suspension achieved a $100 \%$ control of Colletotrichum capsici and Colletotrichum gloesporioides when the pepper seeds were soaked for 24 hours. Ginger aqueous extract recorded the least control of $25.8 \%$ compared with the other botanical extracts in the control of Colletotrichum capsici and Colletotrichum gloesporioides (Table 5). Significant differences were observed between the botanical extracts and water in the control of $C$. capsici and $C$. gloesporioides (Table 5). Significant difference was observed between the botanical extracts and water (control) in the control of Fusarium verticillioides and Fusarium solani (Table 5). Mancozeb achieved a 100\% control of $F$. verticillioides and $F$. solani followed by ginger $79.8 \%$, Neem $51.3 \%$ and the least control was recorded by garlic $41.3 \%$ (Fig. 5). Ginger, neem and mancozeb achieved a $100 \%$ control of Aspergillus flavus and Aspergillus niger found on pepper seeds. Garlic aqueous extract recorded the least control of $11.1 \%$ but there was however, significant difference between aqueous garlic extract and water in the control of A. flavus and A. niger (Table 5). 
TABLE 5

Effect of treatments in the control of the major seed-borne pathogens of pepper

\begin{tabular}{|c|c|c|c|}
\hline \multirow[b]{2}{*}{ Treatments } & \multicolumn{2}{|c|}{ Percentage control of the major seed-borne fungi (\%) } & \multirow[b]{2}{*}{$\begin{array}{l}\text { A. flavus and } \\
\text { A. niger }\end{array}$} \\
\hline & $\begin{array}{l}\text { C. capsici and } C \text {. } \\
\text { gloesporioides }\end{array}$ & $\begin{array}{c}\text { F. solani and } \\
\text { F. verticillioides }\end{array}$ & \\
\hline Water & $0.0^{\mathrm{d}}$ & $0.0^{\mathrm{e}}$ & $0.0^{\mathrm{b}}$ \\
\hline Neem leaf extract & $48.2^{\mathrm{b}}$ & $51.3^{\mathrm{c}}$ & $100.0^{\mathrm{a}}$ \\
\hline Ginger extract & $25.8^{\mathrm{c}}$ & $79.8^{\mathrm{b}}$ & $100.0^{\mathrm{a}}$ \\
\hline Garlic extract & $100.0^{\mathrm{a}}$ & $41.3^{\mathrm{d}}$ & $11.1^{\mathrm{b}}$ \\
\hline Mancozeb (check) & $100.0^{\mathrm{a}}$ & $100.0^{\mathrm{a}}$ & $100.0^{\mathrm{a}}$ \\
\hline Lsd $(5 \%)$ & 5.7 & 5.7 & 5.7 \\
\hline CV $(\%)$ & 6.1 & 6.1 & 6.1 \\
\hline
\end{tabular}

Values with different letters in a column are significantly different at $\mathrm{p}<0.05$

\section{Discussion}

About $75 \%$ of the farmers interviewed in the study area used their own saved seeds of pepper extracted from rotten pepper fruits for planting. This according to the farmers saves them from spending their scanty resources on buying seeds for planting. According to Isaac (1992), over $70 \%$ of farmers in developing countries use their own saved seeds continuously for planting. However, none of the famers treated their pepper seeds with appropriate fungicide or botanical extract before planting. Continuous use of farmer-saved seeds in the absence of seed treatment could contribute to high incidence of seed-borne diseases.

Nine genera of fungi including 12 species were identified from the pepper seed samples collected from the two communities. Colletotrichum capsici, Fusarium solani, Fusarium oxysporum, Aspergillus niger, Aspergillus flavus, Rhizopus stolonifer, Curvularia sp. and Penicillium sp. have been identified on chilli pepper seeds in other studies (Chauhan \& Patel, 2018; Dinker \& Gunay, 2018; Chigoziri \& Ekefan, 2013; Balogun et al., 2005). A number of the seed-borne fungi of pepper identified in this study cause field diseases. Colletotrichum capsici and Colletotrichum gloesporioides are known to cause anthracnose disease of pepper (Than et al., 2008; Pakdeevaraporn et al., 2005; Sharma et al., 2005; Voorrips et al., 2004). Fusarium solani and Fusarium verticillioides found on about 35.0 and $30.0 \%$, respectively, of seed samples from Ofoase-Kokoben is worth noting because both fungi cause wilt diseases of pepper. Training farmers in skills to control seed-borne fungi of pepper through the use of appropriate botanical extracts would go a long way to reduce over dependence on chemical fungicides.

To establish the efficacy of botanical extracts in controlling seed-borne pathogens, no single botanical product was completely effective against all the major seed-borne pathogens identified. However, aqueous garlic extract showed fungicidal activity against Colletotrichum capsici and C. gloesporioides. Ginger rhizome extract was also effective in controlling Fusarium verticillioides, Fusarium solani, Aspergillus flavus and Aspergillus niger whilst neem leaf extract was effective in controlling Aspergillus flavus and Aspergillus niger. Aqueous garlic and ginger rhizome extracts have been shown by several workers to possess fungicidal properties. Syed (2012) reported that garlic was equally effective as Mancozeb in controlling Colletotrichum species on sorghum and groundnut seeds. Ines et al. (2008), using different botanicals including garlic, neem, malunggay (Moringa oleifera) 
and Dithene M-45 to control anthracnose disease of mango seedlings reported that garlic and the fungicide were better in controlling the fungi. Shovan et al. (2008) also used different botanical extracts to control Colletotrichum dematium causing anthracnose disease in soybean and reported that garlic extract appeared to be the best in inhibiting the growth of the fungus. In the current study, ginger aqueous extract was effective in controlling Fusarium verticillioides, F. solani, Aspergillus flavus and $A$. niger. This result is in line with the findings of Fawzi et al. (2009) who found ginger to be effective in inhibiting the growth of Fusarium oxysporum. Aidoo (2011) also reported that ginger extract was active in inhibiting the growth of Fusarium oxysporum. Ginger rhizome extracts have been shown to possess a broad range of biological activity against fungi (Foster \& Yue, 1992).

Neem leaf extract was found in this study to be very effective in controlling $A s$ pergillus flavus and A. niger on seeds of pepper but showed less fungicidal activity against Colletotrichum capsici and Colletotrichum gloesporioides. This result corroborates the findings by Ines et al. (2008) using different botanicals including garlic, neem, malunggay and Dithene M-45 to control anthracnose disease of mango seedlings. These authors reported that garlic showed the least mean number of infected leaves followed by neem and thus concluded that the use of garlic and neem botanical extracts in controlling anthracnose of mango seedlings was promising.

\section{Conclusion}

Results of the questionnaire-based survey indicated that, majority of respondent farmers did not use certified seeds because the farmers recycle seeds from previous harvest. All the farmers interviewed also did not treat their pepper seeds before sowing. Nine genera of fungi including 12 species were identified from the pepper seed samples collected from the two communities. Several of the seed samples tested for the presence of seed-borne pathogens carried high infections of Colletotrichum capsici. This high incidence gives an indication that Colletotrichum capsici, one of the causal organisms of anthracnose of pepper could be transmitted or could spread largely in the two studied communities through infected seeds.

Aqueous garlic and ginger rhizome extracts $(60 \%(\mathrm{w} / \mathrm{v}))$ were found to be effective in controlling seed-borne Colletotrichum capsici and C. gloesporioides; and Aspergillus flavus and Aspergillus niger respectively. Aqueous neem leaf extract $(60 \%(\mathrm{w} / \mathrm{v}))$ was found to be effective in controlling Aspergillus flavus and Aspergillus niger.

\section{Recommendations}

- The use of certified pepper seeds for sowing is recommended to prevent the introduction of disease-causing agents unto the field.

- In areas where farmers recycle their saved seeds, treatment of the seeds with appropriate aqueous botanical extract is encouraged to stem the introduction of disease-causing pathogens unto the field through the infected seeds.

\section{REFERENCES}

Aidoo, A.K. (2011) Yam tuber rot: Identification and control of pathogens in storage. Master of Science thesis submitted to Faculty of Agriculture, KNUST, Kumasi. pp. 40

Al-Askar, A.A., Ghoneem, K.M. \& Rashad, Y.M. (2013) Management of some seed-borne pathogens attacking alfalfa plants in Saudi 
Arabia. African Journal of Microbiology

Research 7 (14), 1197 - 1206.

Balogun, O.S., Odeyemi, G.A. \& Fawole, O.B. (2005) Evaluation of the pathogenic effect of some fungal isolates on fruits and seedlings of pepper (Capsicum species). Journal of Agricultural Research and Development 4 (2), $159-169$.

Barnett, H.L. \& Hunter, B.B. (1998) Illustrated Genera of Imperfect Fungi. 4th Edition. APS Press, St Paul, Minnesota.

Bosland, P.W. \& Votava E.J. (2003) Peppers: Vegetable and Spice Capsicums. England: $\mathrm{CAB}$ International. pp. 233.

Chauhan, R.T., Patel, P.R. \& Thumar, V.M. (2018) Occurrence of seedborne pathogens in chilli (Capsicum frutescens L.) cv GVC 111 in-vitro. International Journal of Chemical Studies 6 (2), $1374-1376$.

Chigoziri, E. \& Ekefan, J.E. (2013) Seedborne fungi of chilli pepper from pepper producing areas of Benue State, Nigeria. Agriculture and Biology Journal of North America 4, 370 374.

Debnath, M., Sultana, A. \& Rashid, A.Q.M.B. (2012) Effect of seedborne fungi on the germinating seeds and their bio-control in Maize. Journal of Environment, Science and Natural Resources 5 (1), 117 - 120.

Dinker, H. \& Gunay, M. (2018) Determination of fungal agents in some vegetables seeds in greenhouse production areas in Usak Province. International Journal of Agriculture and Forestry 8 (2), $83-91$.

Fawzi, E.M., Khalil, A.A. \& Afifi, A.F. (2009) Antifungal effects of some plant extracts on $\mathrm{Al}$ ternaria alternata and Fusarium oxysporum. African Journal of Biotechnology 8 (11), $2590-2597$.
Foster, S. \& Yue, C.X. (1992) Herbal emissaries: Bringing Chinese herbs to the West. Rochester, Vt: Healing Arts Press. pp. 67.

Ines, M.C., Pascua, G.S. \& Pascua, G.F.S. (2008) Botanical materials as alternative control against anthracnose disease of mango seedlings. PCARRD Highlights. $78-88$.

International Seed Testing Association (ISTA). (2005) Proceedings of the International Seed Testing Association. International Rules of Seed Testing. Seed Science and Technology 15, $1-9$.

Isaac, S. (1992) Fungal Plant Interaction. London: Chapman and Hall Press. pp. 115.

Jalili-Marandi, R., Hassani, A., Ghosta, Y., Abdullahi, A., Pirzad, A. \& Sasidkon, F. (2010) Thymus kotschyanus and Carum copticum essential oils as botanical preservatives for table grape. Journal of Medicinal Plants Research 4 (22), $2424-2430$.

Jeyalakshmi, C. \& Seetharaman, K. (1998) Biological control of fruit rots and die-back of chilli with plant products and antagonistic microorganisms. Plant Disease Research 13, $46-48$.

Korpraditskul, V., Rattanakreetakul, C., Korpraditskul, R. \& Pasabutra, T. (1999) Proceeding of Kasetsart University Annual Conference. Bangkok: Kasetsart University; Development of plant active substances from Sweetflag to control fruit rot of mango for export. pp. 34 .

Makelo, M.N. (2010) Assessment of seed-borne pathogens for some important crops in Western Kenya, Machakos Kenyan. 1 - 7.

Marin, A., Ferreres, F., TomásBarberán, F.A. \& Gil, M. (2004) Characterization and quantization of antioxidant constituents of sweet pepper (Capsicum annuum L.). Journal of Agricultural and Food Chemistry 52 (12), $3861-3869$. 
Mathur, S.B. \& Kongsdal, O. (2003) Common Laboratory Seed Health Testing Methods for Detecting Fungi. Published by International Seed Testing Association (ISTA). Bassersdorf, CH., Switzerland. pp. 89.

Maude, R. B. (1996) Seed-borne diseases and their Control. CAB Inter. Cambridge pp. 280.

Nuzhat, T. \& Vidyasagar, G.M. (2013) Antifungal investigations on plant essential oils. A review. International Journal of Pharmacy and Pharmaceutical Sciences 5 (2), 19 - 28.

Okigbo, R. N. (2004) A review of biological control methods for post-harvest yams in storage in South Eastern Nigeria. KMITL. Journal of Science 4, 207 - 215.

Osuna-García, J.A., Wall, M.W. \& Waddell, C.A. (1998) Endogenous levels of tocopherols and ascorbic acid during fruits ripening of New Mexican-type chili (Capsicum annuum L.) cultivars. Journal of Agricultural and Food Chemistry 46 (12), 5093 - 5096.

Pakdeevaraporn, P., Wasee, S., Taylor, P.W.J. \& Mongkolporn, O. (2005) Inheritance of resistance to anthracnose caused by Colletotrichum capsici in Capsicum. Plant Breeding 124 (2), 206 - 208.

Schippers, R.R. (2000) African Indigenous Vegetables, McGraw Hills. 120-121.

Sharma, P.N., Kaur, M., Sharma, O.P., Sharma, P. \& Pathania, A. (2005) Morphological, pathological and molecular variability in Colletotrichum capsici, the cause of fruit rot of chillis in the subtropical region of north-western India. Journal of Phytopathology 153 (4), 232 - 237.

Shovan, L.R., Bhuiyan, M.K.A., Begum, J.A. \& Perez. Z. (2008) In vitro control of Colletotrichum dematium causing anthracnose of soybean by fungicides, plant extracts and Trichoderma harzianum. International Journal of Sustainable Crop Production 3 (3), $10-17$.

Syed, D.Y.N., Robiel, N., Robiel. W. \& Tekle Z. (2012) Efficacy of garlic extract and Mancozeb against seed-borne fungal pathogen of farmer-saved sorghum and groundnut seeds. Journal of Agricultural Sciences 2 (2), 31 36.

Than, P.P., Jeewon, R., Hyde, K.D., Pongsupasamit, S., Mongkolporn, O. \& Taylor, P.W.J. (2008) Characterization and pathogenicity of Colletotrichum species associated with anthracnose disease on chilli (Capsicum spp.) in Thailand. Plant Pathology 57 (3), $562-572$.

Tindall, H.D. (1983) Vegetable in the tropics. Mac Millan, London. $352-354$.

Voorrips, R.E., Finkers, R., Sanjaya, L. \& Groenwold, R. (2004) QTL mapping of anthracnose (Colletotrichum spp.) resistance in a cross between Capsicum annuum and $C$. chinense. Theoretical and Applied Genetics 109 (6), 1275 - 1282. 